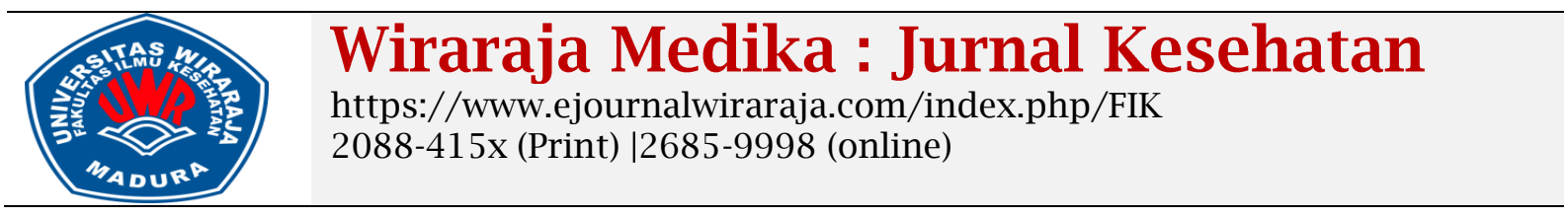

\title{
Stigma Masyarakat Terhadap Penderita Kusta di Kecamatan Batuputih Sumenep
}

\author{
Mujib Hannan ${ }^{1}$, Syaifurrahman Hidayat ${ }^{2}$, Mayank Nirmala Sandi ${ }^{3}$ \\ 1,2,3Fakultas Ilmu Kesehatan, Universitas Wiraraja \\ mujib@wiraraja.ac.id*,dayat.fik@wiraraja.ac.id,nirmalasandimayank@gmail.com \\ Corresponding Author*
}

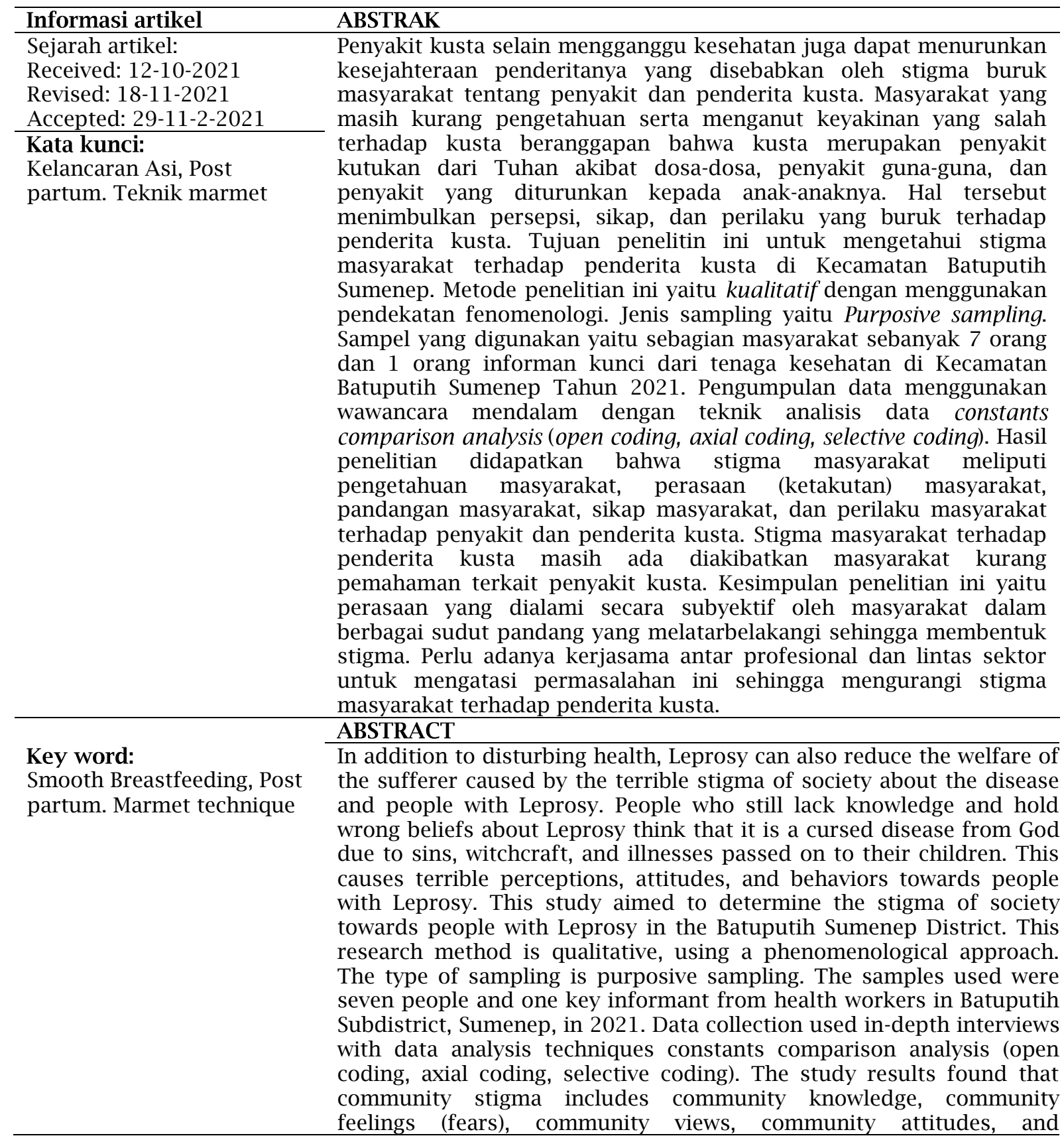


community behavior towards diseases and people with Leprosy. The community's stigma against people with Leprosy still exists due to a lack of understanding about Leprosy. This study concludes that the feelings experienced subjectively by the community in various perspectives are the background to form a stigma. There is a need for inter-professional and cross-sector collaboration to overcome this problem and reduce society's stigma towards people with Leprosy.

\section{PENDAHULUAN}

Pembangunan berkelanjutan (TPB) yang memiliki 17 tujuan, diantaranya yaitu kehidupan sehat dan sejahtera (Badan Pusat Statistik, 2018). Kehidupan sehat dan sejahtera di Indonesia masih terus dikembangkan, hal yang masih menjadi masalah yaitu tingkat penularan penyakit yang tinggi, salah satunya penyakit menular kusta. Penyakit kusta selain mengganggu kesehatan dapat juga mengganggu kesejahteraan penderita dikarenakan stigma masyarakat yang buruk terhadap penyakit dan penderita kusta ini. Stigma adalah persepsi buruk atau negatif dan dapat menimbulkan perlakuan diskriminatif terhadap penderita kusta. Perlakuan diskriminatif dapat terjadi dalam beberapa kesempatan, misalnya mencari lapangan pekerjaan, menggunakan transportasi umum, beribadah di tempat ibadah, mendapatkan pasangan hidup, dan lain-lain. Hal ini dapat menghambat penderita kusta ataupun keluarganya dalam menjalani proses sosial dan status ekonomi, karena adanya penolakan dari masyarakat ataupun respon menyalahkan.

Pada tahun 2015 kasus kusta di dunia berjumlah sekitar 210.758. Kasus tersebut banyak terjadi di bagian Asia Tenggara yaitu 156.118 kasus kemudian diikuti Amerika 28.806 kasus, Afrika 20.004 kasus, dan sisanya berada di negara bagian lain (Pusat Data dan Informasi Kementerian Kesehatan RI, 2018). Indonesia berada pada peringkat ketiga di dunia dengan penemuan kasus baru kusta terbanyak yaitu 17.202 jiwa pada tahun 2015 setelah brazil. Jawa Timur berada pada peringkat pertama dengan jumlah kasus baru kusta terbanyak pada tahun 2018 yaitu dengan jumlah 2.701 jiwa (Pusat Data dan Informasi Kementerian Kesehatan, 2019). Kabupaten Sumenep yang terletak di Provinsi Jawa Timur tergolong tinggi penemuan kasus baru kusta yaitu 327 jiwa, baik penderita kusta tipe pausi basiler $(\mathrm{PB})$ maupun multi basiler
(MB) dengan menduduki peringkat ketiga setelah Kabupaten Pamekasan pada tahun 2019 (Dinas Kesehatan Provinsi Jawa Timur, 2020). Sebanyak 30 puskesmas yang berada di Kabupaten Sumenep terdapat kasus kusta dari jumlah terendah hingga tertinggi. Puskesmas Batuputih menduduki peringkat kedua penderita baru dengan total 35 jiwa setelah puskesmas Gayam dengan total 42 jiwa pada tahun 2019 (Dinas Kesehatan Kabupaten Sumenep, 2020).

Studi pendahuluan yang dilakukan pada bulan Februari 2021 dengan cara wawancara langsung dengan 3 warga di Kecamatan Batuputih mengatakan bahwa mereka tidak paham dengan penyakit kusta, mereka hanya mengetahui bahwa penyakit kusta merupakan penyakit menular, penyakit guna-guna, dan menakutkan. Salah satu dari 3 warga tersebut merupakan kader di Kecamatan Batuputih. Beliau mengatakan bahwa masyarakat yakin kusta ditularkan dari pakaian yang sama, sabun yang digunakan dari penderita kusta, hubungan seksual yang lebih dari satu pasangan. Adapun warga yang lain mengatakan bahwa pada saat tetangga dekatnya menderita kusta, dia tidak menjenguknya.

Berdasarkan penelitian yang dilakukan oleh Tosepu, Gunawan, Effendy, \& Fadmi (2018) penderita kusta mengalami tekanan besar yaitu stigma dari komunitasnya. Stigma terkait kusta masih sangat kuat di masyarakat, mereka beranggapan bahwa kusta penyakit yang diturunkan, memalukan, dan tidak diterima di masyarakat. Hal ini juga memengaruhi kehidupan penderita kusta serta menghambat proses perawatan penyakitnya dan mungkin mengarah ke kusta progresif. Peran masyarakat terhadap penderita kusta seharusnya menjadi sumber pendukung. Sehubungan dengan ini maka perlu diteliti stigma masyarakat terhadap penderita kusta. Masyarakat tidak perlu memiliki rasa takut berlebihan (lepraphobia) karena penyakit 
kusta dapat disembuhkan dengan perawatan dan pengobatan yang tepat dengan MDT (Multi Drug Therapy) sesuai rekomendasi dari WHO (World Health Organization, 2019).

\section{METODE PENELITIAN}

Desain yang digunakan dalam penelitian ini yaitu kualitatif. Penelitian kualitatif melakukan pendekatan yang mendeskripsikan dan menganalisis budaya beserta perilaku individu dan kelompok dari sudut pandang mereka yang diteliti. Penelitian ini menggunakan pendekatan fenomenologi, Tempat penelitian ini dilakukan di Kecamatan Batuputih Kabupaten Sumenep. Penelitian ini dilakukan pada bulan Mei Tahun 2021. Pemilihan informan menggunakan purposive sampling. Sampel yang digunakan yaitu sebanyak 7 informan masyarakat dan 1 informan kunci dari tenaga kesehatan puskesmas di Kecamatan Batuputih Kabupaten Sumenep Tahun 2021. Teknik pengumpulan data menggunakan wawancara mendalam.

\section{HASIL DAN PEMBAHASAN}

Hasil penelitian didapatkan bahwa stigma masyarakat meliputi pengetahuan masyarakat, perasaan (ketakutan) masyarakat, pandangan masyarakat, sikap masyarakat, dan perilaku masyarakat terhadap penyakit dan penderita kusta. Sedangkan konsep diri penderita kusta meliputi identitas diri, gambaran diri, harga diri, ideal diri, dan peran diri penderita kusta.

Tabel 1. Karakteristik Informan

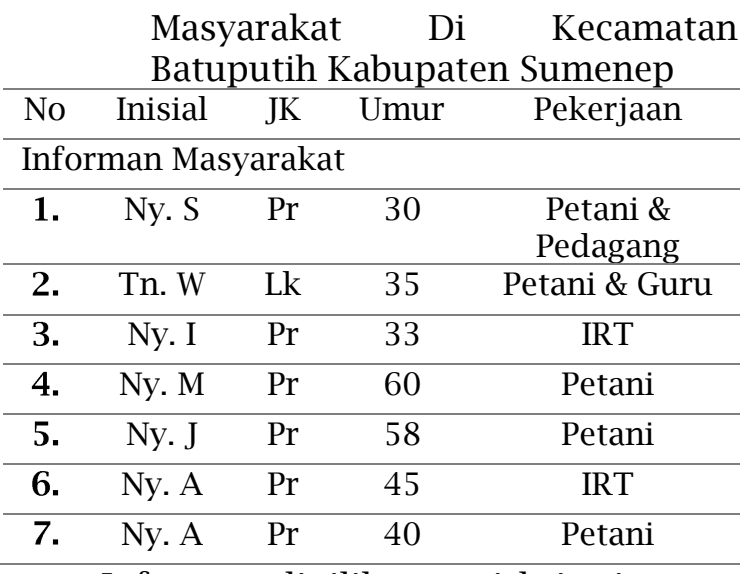

Informan dipilih sesuai kriteria yang ditentukan peneliti. Kriteria informan masyarakat yaitu lokasi rumah informan dekat dengan rumah penderita kusta maksimal dengan jarak 150 meter.
Informan masyarakat berjumlah 7 orang dengan usia 30 sampai 60 tahun. Semua informan masyarakat terdiri dari 1 orang laki-laki dan 6 orang perempuan, dengan memiliki pekerjaan sebagai petani sebanyak 5 orang dan 2 orang sebagai ibu rumah tangga. Adapun 1 orang laki-laki informan masyarakat selain menjadi petani juga berprofesi sebagai guru di SMP. Informan kunci pada penelitian ini yaitu 1 orang laki-laki tenaga kesehatan yang memegang program penyakit kusta di Puskesmas Batuputih, dengan usia 56 tahun sebagai PNS. Dipilihnya sebagai informan kunci karena beliau yang sering melakukan kontak dengan penderita kusta di Kecamatan Batuputih.

Stigma Masyarakat Terhadap Penderita Kusta

a. Pengetahuan Masyarakat tentang Penyakit Kusta

Semua informan masyarakat kurang mengetahui secara pasti tentang penyakit kusta, namun mereka mampu menyebutkan gejala-gejala umum pada penyakit kusta yaitu bercak putih. Semua informan masyarakat juga mengungkapkan bahwa tidak ada ataupun tidak mengetahui adanya penyuluhan kesehatan yang memberikan informasi terkait penyakit kusta. Didapatkan informasi dari informan kunci yaitu tenaga kesehatan mengadakan penyuluhan ketika ada penderitanya. Berdasarkan hasil wawancara dengan infroman:

I1: "tidak ada"

I2: "tidak tau, yang putih-putih itu seperti gatal-gatal"

I3: "berbentuk lingkaran seperti uang koin, terus ada yang jarinya lepas"

I4: "tidak tau, ya, berbentuk lingkaran putih-putih"

I5: "tidak tau, ada itu $\mathrm{N}$ dan ibunya A katanya kusta"

I6: "tidak ada kalau itu disini"

I7: "putih berbentuk lingkaran seperti uang koin"

Pendidikan kesehatan sebagai bagian dari promosi kesehatan merupakan suatu bentuk usaha dalam menyampaikan pesan atau pengetahuan tentang kesehatan kepada masyarakat, kelompok, atau individu (Notoatmodjo, 2005). Sejalan dengan penelitian yang dilakukan oleh Sodik (2016) masyarakat atau tetangga yang rumahnya berdekatan dengan penderita kusta 
memiliki pengetahuan yang bermacammacam ada yang memiliki pengetahuan luas dan ada juga yang kurang memiliki pengetahuan tentang penyakit kusta yang sebenarnya, hal tersebut terjadi mengingat kurangnya sosialisasi Puskesmas atau tenaga kesehatan lainnya kepada masyarakat tentang arti penyakit kusta itu sendiri.

Opini peneliti dalam hal ini yaitu pengetahuan yang kurang pada masyarakat karena ada beberapa faktor. Faktor internal pada masyarakat itu sendiri yang kurang antusias untuk menerima atau mencari kebenaran tentang penyakit kusta. Faktor eksternal karena dari tenaga kesehatan yang mengadakan penyuluhan ketika ada penderitanya dan hanya perwakilan saja serta informasi yang tidak merata pada kalangan masyarakat tentang penyakit kusta.

b. Perasaan/Ketakutan Masyarakat Terhadap Penyakit dan Penderita Kusta

Kurangnya pengetahuan pada masyarakat terkait kusta dapat menimbulkan persepsi yang salah, sehingga hal ini dapat memicu perasaan takut. sebagian besar masyarakat memiliki perasaan takut salah satunya takut tertular dan gejala yang ditimbulkan dari penyakit kusta. Berdasarkan hasil wawancara dengan informan:

I1: "saya merasa tidak ragu, perasaan saya pasrah biasa karena katanya yang merasa ragu yang sering tertular"

I2: "ya takut"

I3: "ya tetap merasa takut karena sebelumnya tidak pernah terkena penyakit seperti itu terus muncul bulatbulat"

I4: "ya takut tetapi kalau ada acaraacara misalnya tetap bergabung, menular katanya"

I5: "ya takut gimana gitu ke orangnya takut menular"

I6: "ya tetap merasa takut terus ada luka di kakinya, menjijikkan, takut menular"

I7: "tetap merasa takut, takut menular" Ketakutan adalah suatu daya penggerak stigma yang utama. Masyarakat umumnya takut pada dua hal, yaitu kelainan bentuk suatu penyakit dan pengeluaran dari kehidupan sosial. Ketakutan karena risiko transmisi penyakit merupakan aspek yang umumnya juga terjadi di masyarakat. Para petugas kesehatan kadang-kadang juga tidak mau bekerja sama dalam menangani klien kusta di masyarakat (Nations, 2009).

Sejalan dengan penelitian yang dilakukan oleh Sulidah (2016) yaitu masyarakat takut tertular, takut ikut kena kutukan, menganggap penderita kusta sebagai pembawa sial, atau takut dirinya akan mendapatkan perlakuan yang sama bila berhubungan dengan penderita kusta.

Opini peneliti dalam hal ini yaitu ketakutan masyarakat ditimbulkan karena kurangnya pemahaman masyarakat tentang cara penularan kusta. Pada umumnya masyarakat tidak tau secara pasti tentang penyakit kusta sehingga hal ini menimbulkan ketakutan atau kekhawatiran akan tertular, takut dengan gejala dan dampak yang ditimbulkan kusta.

c. Pandangan Masyarakat Terhadap Penyakit dan Penderita Kusta

Pandangan masyarakat terhadap penyakit kusta didasarkan pada pengetahuan yang mereka miliki dan fenomena yang terjadi di lingkungan masyarakat sekitar. Semua informan masyarakat mengatakan bahwa kusta merupakan penyakit menular. Tetapi mereka tidak tau secara pasti penyebab dari penyakit kusta. Pemikiran kusta sebagai penyakit kutukan Tuhan, darah najis, akibat dosa-dosa telah bergeser, tetapi masih ada sebagian kecil masyarakat yang berkeyakinan kusta merupakan penyakit guna-guna Berdasarkan hasil wawancara dengan informan:

I1: "ya menular tetapi kalau golongan darahnya tidak sama tidak menular, kalau kusta disebabkan dari orangnya sendiri"

I2: "menular, menurut saya penyakit kusta pemberian dari Yang Maha Kuasa" I3: "katanya menular, kalau disini tidak menyangka-menyangka dari mana penyebab kusta tetapi tetap dari Yang Maha Esa"

I4: "penyakitnya bisa menular, tidak tau tetapi sebagian karena guna-guna orang"

I5: "katanya kalau penyakit kusta gelas minum dan gayung tidak boleh digunakan bergantian langsung menular 
tetapi kalau darahnya sama kalau tidak sama tidak menular katanya"

I6: "biasanya yang sakit tidak keluaran rumah bisa menular penyakitnya, ya paling penderita kusta merasa sendiri menjauh, tidak tau kalau itu ya disebabkan dari orangnya sendiri"

I7: "katanya kalau menderita kusta pakaian dan sabunnya tidak boleh bergantian dengan yang lain bisa menular, tidak paham penyebab dari kusta"

Persepsi seseorang yaitu berbagai persepsi individu yang dibuat oleh individu tentang individu lainnya (Robbins \& Judge, 2008). Sejalan dengan penelitian yang dilakukan oleh Sodik (2016) yaitu persepsi masyarakat terhadap penderita kusta bermacammacam ada sebagian kecil masyarakat yang berpersepsi baik kepada penderita kusta, tetapi tidak bisa dipungkiri lagi mayoritas masyarakat yang menjadi informan berpersepsi penyakit kusta adalah penyakit menular yang menakutkan dan penderitanya perlu dijauhkan.

Opini peneliti dalam hal ini yaitu pandangan atau persepsi masyarakat terhadap penyakit dan penderita kusta dipengaruhi oleh pemahaman dan fenomena yang mengakar di lingkungan masyarakat sehingga penyakit kusta dalam pandangan masyarakat disampaikan dari mulut ke mulut yang belum bisa dipertanggungjawabkan kebenarannya. Dibutuhkan informasi yang jelas terkait penyakit kusta supaya pemikiran keliru dari penyakit ini bisa diluruskan.

d. Sikap Masyarakat Terhadap penderita Kusta

Budaya dapat memengaruhi sikap masyarakat. Rata-rata masyarakat cenderung bersikap seperti biasa kepada penderita kusta karena faktor lingkungan sekitar meski takut. Berdasarkan hasil wawancara dengan informan:

I1: "tidak menjenguknya, karena sendiri-sendiri"

I2: "ya seperti biasa"

I3: "ya saya seperti biasa kalau menjauh nanti dikira gimana gitu, sebenarnya takut tapi nanti dibicarakan gimana gitu kalau disini"
I4: "ya takut tidak menjenguknya, takut menular"

I5: "ya gak gimana gimana takut tapi ya seperti biasa pasrah kepada Tuhan semoga dijauhkan dari penyakit itu" I6: "ya gimana gitu yang sakit langsung tidak keluaran rumah ya seperti biasa meski takut, ya seperti biasa gimana gitu tapi agak menjauh sedikit kalau bergabung tetap ada perasaan takut dalam hati, setau saya sendiri-sendiri yang sakit menjauh sendiri, ya yang sakit sadar jadi menjauh dari orangorang"

I7: "tidak menjenguknya, ya gimana gitu yang sakit juga tidak keluaran rumah, ya seperti biasa meski takut"

Menurut Susanto (2013) dalam bukunya sikap merupakan faktor penyebab stigma yang paling besar. Sikap adalah suatu respon yang dipelajari dan diwujudkan dalam bentuk aktivitas sosial. Sikap umumnya merupakan hasil pengalaman masa lalu dan sering juga digambarkan dalam kaitannya dengan kepercayaan (evaluasi), keyakinan (perasaan), dan kecenderungan perilaku.

Sejalan dengan penelitian yang dilakukan oleh Sodik (2016) yaitu sikap masyarakat bermacam-macam seperti sebagian kecil masyarakat bisa bersikap baik kepada penderita kusta tersebut, tetapi tidak bisa dipungkiri lagi bahwa kebanyakan masyarakat yang menjadi informan bersikap mendiskriminasi penderita kusta. Opini peneliti dalam hal ini yaitu masyarakat rata-rata bersikap seperti biasa karena dipengaruhi faktor budaya di tempat tinggal mereka. Mereka merasa tidak nyaman dan khawatir dibicarakan orang lain jika menjauh dari penderita kusta. Mereka tetap bersikap biasa meski mengungkapkan rasa ketakutannya. Namun penderita kusta menjauh sendiri menurut pernyataan masyarakat. Mungkin penderita kusta disini merasakan stigma dari masyarakat lain yang tidak bersikap seperti biasa atau stigma dari diri mereka sendiri.

e. Perilaku Masyarakat Terhadap penderita Kusta

Perilaku menggambarkan tanggapan atau reaksi individu terhadap rangsangan atau lingkungan. Informan masyarakat semua berperilaku baik kepada penderita kusta dengan mengundang penderita kusta pada 
acara-acara tertentu. Meskipun ada informan yang tetap merasa takut jika berkumpul dengan penderita kusta. Berdasarkan hasil wawancara dengan informan:

I1: "ya kalau itu diundang tidak bisa milih-milih siapa yang diundang datang tidaknya terserah, kan tidak enak perasaan"

I2: "ya diundang seperti lainnya kalau disini tetap diundang masalah datang tidaknya terserah tetapi banyak yang tidak datang"

I3: "kalau itu tetap diundang masalah datang tidaknya terserah tetapi biasanya banyak yang tidak datang, orangnya menjauh sendiri"

I4: "tetap diundang, tidak enak"

I5: "tetap diundang kan tidak enak meski takut ya diam langsung pasrah kepada Tuhan"

I6: "kalau itu tetap diundang kan tidak enak ya kadang tidak datang meski diundang penderitanya menjauh dari orang-orang seperti A yang sakit kusta tidak bergabung langsung menjauh ke yang lain, kan tidak enak kalau bergabung tetap ada perasaan takut agak menjauh sedikit ya semoga tidak menular"

I7: "tetap diundang kalau ada acaraacara kan tidak enak kalau tidak diundang, ada yang datang tetapi banyak yang tidak datang biasanya, ya paling sadar kan muncul putih bulatbulat seperti uang koin mungkin malu"

Kemungkinan sebuah sikap terwujud sebagai perilaku, digambarkannya dengan teori yang disebut "teori perilaku yang direncanakan" (theory of planned behavior). Ada tiga komponen yaitu sikap terhadap tingkah laku, norma subyektif, dan keyakinan mampu mengendalikan perilaku, berkombinasi menentukan intensi (niat) seseorang untuk menampilkan perilaku tertentu (Widyarini, 2009).

Robbins \& Judge (2008) dalam bukunya mengemukakan penelitian yang sebelumnya tentang sikap menganggap bahwa sikap mempunyai hubungan sebab akibat dengan perilaku, yaitu sikap yang dimiliki individu menentukan apa yang mereka lakukan. Namun pada akhir tahun 1960-an, hubungan yang diterima tentang sikap dan perilaku ditentang oleh sebuah tinjauan penelitian. Berdasarkan evaluasi sejumlah penelitian yang menyelidiki hubungan sikap dan perilaku, peninjau menyimpulkan bahwa sikap tidak berhubungan dengan perilaku atau paling banyak hanya berhubungan sedikit. Ketidaksesuaian antara sikap dan perilaku kemungkinan besar muncul ketika tekanan sosial untuk berperilaku dalam cara-cara tertentu memiliki kekuatan yang luar biasa.

Opini peneliti dalam hal ini yaitu masyarakat umumnya berperilaku baik kepada penderita kusta dengan tetap mengundang penderita kusta pada acaraacara tertentu dikarenakan perasaan yang tidak enak dan juga budaya yang melekat di daerah tersebut yang mengundang tetangga sekitarnya jika ada acara. Termasuk halnya masyarakat yang memiliki sikap kurang baik kepada penderita kusta juga menunjukkan perilaku yang baik dengan tetap mengundang penderita kusta pada acara tertentu. Kemungkinan hal ini muncul karena adanya tekanan sosial yang berpengaruh pada masyarakat untuk berperilaku tersebut seperti budaya yang ada disana.

\section{KESIMPULAN}

Berdasarkan penelitian bahwa stigma masyarakat terhadap penderita kusta masih ada diakibatkan masyarakat kurang mengetahui secara pasti tentang penyakit kusta. Dibutuhkan kerjasama lintas sektor dan mendukung program pemberantasan penyakit kusta dengan turut membantu proses sosialisasi atau penyuluhan kesehatan kepada masyarakat dan mengevaluasi kegiatan tersebut. Sebaiknya masyarakat lebih antusias dan berpartisipasi untuk mencari/memperoleh informasi terkait penyakit kusta ini, tidak hanya berdiam saja mendengar informasi yang salah dalam mengartikan penyakit kusta.

\section{DAFTAR PUSTAKA}

Amiruddin, 2019. Penyakit Kusta "Sebuah Pendekatan Klinis". Surabaya: Brilian Internasional.

Aulia, P. W., 2019. Stigma Terhadap Penderita Kusta (Studi Tentang Bentuk Stigma dan Reaksi Terhadap Stigma yang Dialami Penderita Kusta dalam Proses Pengobatan di Kabupaten 
Mojokerto). Perpustakaan Universitas Airlangga, p. 5.

Badan Pusat Statistik, 2018. Indikator Tujuan Pembangunan Berkelanjutan (TPB) Indonesia 2018. Jakarta: BPS-Statistics Indonesia.

Dinas Kesehatan Kabupaten Sumenep, 2020. Situasi Penyakit Kusta Kabupaten Sumenep Tahun 2019 (31 Desember 2019), Sumenep: Dinas Kesehatan Kabupaten Sumenep.

Dinas Kesehatan Provinsi Jawa Timur, 2020. Umpan Balik Kegiatan Program Pemberantasan Penyakit Kusta Tahun 2019 Per Kabupaten/Kota, Surabaya: Dinas Kesehatan Provinsi Jawa Timur.

Martha, E. \& Kresno, S., 2017. Metodologi Penelitian Kualitatif "Untuk Bidang Kesehatan". Depok: Rajawali Pers.

Nations, 2009. Stigma, Labelling, Dan Diskriminasi Sosial Klien Kusta. In: Perawatan Klien Kusta Di Komunitas. Jakarta: Penerbit Buku Kesehatan, p. 64.

Notoatmodjo, 2005. Pendidikan Kesehatan. In: Perawatan Klien Kusta Di Komunitas. Jakarta: Penerbit Buku Kesehatan, p. 81.

Nunzi, E. \& Massone, C., 2012. Leprosy A Practical Guide. Italia: SpringerVerlag.

Permenkes, 2019. Peraturan Menteri Kesehatan Republik Indonesia Nomor 11 Tahun 2019 Tentag Penanggulangan Kusta, Jakarta: Menteri Kesehatan Republik Indonesia.
Pusat Data dan Informasi Kementerian Kesehatan RI, 2018. Hapuskan Stigma Dan Diskriminasi Terhadap Kusta, Jakarta: Pusdatin Kemkes.

Pusat Data dan Informasi Kementerian Kesehatan, 2019. Data dan Informasi Profil Kesehatan Indonesia 2018, Jakarta: Pusat Data dan Informasi Kementerian Kesehatan.

Robbins, S. P. \& Judge, T. A., 2008. Perilaku Organisasi "Organizational Behavior". Jakarta: Salemba Empat.

Sodik, M. A. (2016). Leprosy Patients In Public Perception: A Qualitative Study Of Patient Confidence (dis) In The Community (Penderita Kusta Dalam Persepsi Masyarakat: Sebuah Studi Kualitatif Tentang Kepercayaan Diri Pasien Di Masyarakat). Journal of Global Research In Public Health, 104.

Sulidah. (2016). Hubungan Pengetahuan Dan Sikap Masyarakat Terkait Kusta Terhadap Perlakukan Diskriminasi Pada Penderita Kusta . Jurnal Medika Respati, 59-60.

Susanto, T., Sahar, J., Permatasari, H., \& Putro, S. E. (2013). Perawatan Klien Kusta Di Komunitas. Jakarta: Penerbit Buku Kesehatan.

Widyarini, N., 2009. Seri Psikologi Populer "Kunci Pengembangan Diri". Jakarta: PT Gramedia.

World Health Organization, 2019. WHO Multidrug Therapy (MDT). [Online] Available at: https://www.who.int/lep/mdt/en/ 